\title{
Process efficiency of casein separation from milk using polymeric spiral-wound microfiltration membranes
}

\author{
D. Mercier-Bouchard, ${ }^{*}$ S. Benoit, ${ }^{*}$ A. Doyen, ${ }^{*}$ M. Britten, $\dagger$ and Y. Pouliot ${ }^{* 1}$ \\ *STELA Dairy Research Center, Institute of Nutrition and Functional Foods, Department of Food Sciences, Université Laval, Québec, QC, \\ Canada, G1V 0A6 \\ †Food Research and Development Centre, Agriculture and Agri-Food Canada, St-Hyacinthe, QC, Canada, J2S 8E3
}

\begin{abstract}
Microfiltration is largely used to separate casein micelles from milk serum proteins (SP) to produce a casein-enriched retentate for cheese making and a permeate enriched in native SP. Skim milk microfiltration is typically performed with ceramic membranes and little information is available about the efficiency of spiral-wound (SW) membranes. We determined the effect of SW membrane pore size $(0.1$ and $0.2 \mu \mathrm{m})$ on milk protein separation in total recirculation mode with a transmembrane pressure gradient to evaluate the separation efficiency of milk proteins and energy consumption after repeated concentration and diafiltration (DF). Results obtained in total recirculation mode demonstrated that pore size diameter had no effect on the permeate flux, but a drastic loss of casein was observed in permeate for the $0.2-\mu \mathrm{m}$ SW membrane. Concentration-DF experiments (concentration factor of $3.0 \times$ with 2 sequential DF) were performed with the optimal 0.1- $\mu \mathrm{m}$ SW membrane. We compared these results to previous data we generated with the $0.1-\mu \mathrm{m}$ graded permeability (GP) membrane. Whereas casein rejection was similar for both membranes, SP rejection was higher for the $0.1-\mu \mathrm{m}$ SW membrane (rejection coefficient of 0.75 to 0.79 for the $0.1-\mu \mathrm{m}$ SW membrane versus 0.46 to 0.49 for the GP membrane). The 0.1$\mu \mathrm{m}$ SW membrane consumed less energy (0.015-0.024 $\mathrm{kWh} / \mathrm{kg}$ of permeate collected) than the GP membrane (0.077-0.143 kWh $/ \mathrm{kg}$ of permeate collected). A technoeconomic evaluation led us to conclude that the 0.1$\mu \mathrm{m}$ SW membranes may represent a better option to concentrate casein for cheese milk; however, the GP membrane has greater permeability and its longer lifetime (about $10 \mathrm{yr}$ ) potentially makes it an interesting option.
\end{abstract}

Received April 12, 2017.

Accepted July 17, 2017.

${ }^{1}$ Corresponding author: yves.pouliot@fsaa.ulaval.ca
Key words: microfiltration, polymeric spiral-wound membrane, skim milk, process efficiency, energy consumption, membrane fouling

\section{INTRODUCTION}

Pre-concentration of milk before cheesemaking has been extensively performed by UF (Pouliot, 2008) but it can now be achieved by microfiltration (MF). With a process using a pore size diameter of approximately $0.1 \mu \mathrm{m}, \mathrm{CN}$ micelles of average size 0.13 to $0.16 \mu \mathrm{m}$ are rejected, whereas serum protein (SP), lactose, and soluble calcium are recovered on the permeate side (Saboya and Maubois, 2000; Fox and McSweeney, 2003). Pre-concentration of milk by MF offers many benefits: CN-enriched retentates retain their functionality and nutritive properties and permeates with native SP do not contain any residual coagulant, starter culture, lactic acid, or color from the cheesemaking process, which allows SP to have superior functional advantages compared with whey (Britten and Pouliot, 1996; Nelson and Barbano, 2005; Karasu et al., 2010).

Two types of membranes are commonly used for MF processes: tubular ceramic membranes and spiralwound (SW) membranes (Cheryan, 1998; Hu et al., 2015). Tubular ceramic membranes are a popular choice of membrane material for MF applications due to their high thermal resistance, narrow pore size distribution and high hydraulic performance (Zulewska et al., 2009; Fernández García and Rodríguez, 2015). Over time, alternatives have been developed to prevent membrane fouling, which is the main challenge in MF (Guerra et al., 1997). Fouling of MF membranes was reduced by the emergence of the hydraulic concept of the uniform transmembrane pressure (UTP) membrane and then by graded permeability (GP) membranes, which are based on a variation of the porosity in the structure (Saboya and Maubois, 2000; Garcera and Toujas, 2002). More recently, 0.1- $\mu \mathrm{m}$ GP membranes were shown to be efficient in separating CN from skim milk (Hurt et al., 2015). Although several studies have characterized the separation performance of MF membranes, 
very few evaluated process efficiency and quantification of energy consumption in MF. The study done by Tremblay-Marchand et al. (2016) showed that when the $\mathrm{CF}$ was increased to $3.0 \times$ for a $0.1-\mu \mathrm{m}$ GP membrane, energy consumption and total CN loss increased, whereas the SP removal rate decreased. Diafiltration allowed an increase in total SP removal but resulted in a substantial increase in energy consumption and CN losses (Tremblay-Marchand et al., 2016).

The recent introduction of SW MF membranes has attracted some attention. Zulewska and Barbano (2013) studied the separation performance of $0.3-\mu \mathrm{m} \mathrm{SW}$ membranes, but important fouling of the membrane elements by $\mathrm{CN}$ micelles occurred whereas the much smaller SP contributed to a minor amount of membrane pore constriction. With this pore size diameter, the cake layer accumulating at the membrane surface dominates the separation, rather than the membrane itself (Hu et al., 2015; Steinhauer et al., 2015). Compared with GP and UTP membranes, the $0.3-\mu \mathrm{m} \mathrm{SW}$ membrane produced the lowest SP removal rate with a value of $39 \%$, whereas GP and UTP membranes could remove up to 61 and $64 \%$, respectively (Zulewska and Barbano, 2013). Lawrence et al. (2008) also evaluated the performance of SW membranes for CN and SP separation in milk, using 0.3 and $0.5 \mu \mathrm{m}$ pore diameters. Casein rejection increased with the TMP, from $96 \%$ to almost $100 \%$, whereas SP transmission decreased from 22 to $1 \%$, as the TMP increased from 50 to $258 \mathrm{kPa}$ (Lawrence et al., 2008). After one sequential DF, about $50 \%$ of the total SP was removed to the permeate side. Beckman et al. (2010) also evaluated milk protein separation performance using a $0.3-\mu \mathrm{m}$ SW membrane at $50^{\circ} \mathrm{C}$ with a TMP of $100 \mathrm{kPa}$ to a $\mathrm{CF}$ of $3.0 \times$ and successfully removed $70 \%$ of the SP after 2 sequential DF. Zulewska and Barbano (2014) evaluated the effect of DF on the efficiency of SP removal during MF of skim milk. After reaching a CF of $3.0 \times$ and 2 sequential DF, an additional 22 and $7 \%$ of the SP was removed after each DF, respectively, giving a total SP removal of $97 \%$ (Zulewska and Barbano, 2014). Govindasamy-Lucey et al. (2007) showed that SW membranes with a pore size of $0.2 \mu \mathrm{m}$ could produce retentates with an increased CN to true protein (TP) ratio and reduced SP content. It can be hypothesized that with a smaller pore size diameter $(0.1$ or $0.2 \mu \mathrm{m})$, the process efficiency of $\mathrm{CN}$ and SP separation in milk increases, especially because these membranes offer important advantages in cost, compared with ceramic membranes (Papadatos et al., 2003; Beckman and Barbano, 2013; Hu et al., 2015).

The objective of this study was to characterize the performance of $0.1-$ and $0.2-\mu \mathrm{m}$ polyvinylidene difluoride (PVDF) SW membranes by $\mathrm{MF}$ at $50^{\circ} \mathrm{C}$ in terms of gain in yield and process efficiency for the separa- tion of CN from milk, compared with GP membrane performance. The investigation on each type of MF membrane was designed to help guiding industrial decisions based on the needs, values, and constraints of dairy processors.

\section{MATERIALS AND METHODS}

\section{Raw Material}

Pasteurized skim milk was purchased from a local dairy supplier (Natrel, Québec, Canada) and stored at $4^{\circ} \mathrm{C}$ until use in MF experiments. For total recirculation experiments performed with SW membranes of 0.1 - and $0.2-\mu \mathrm{m}$ pore diameters, 2 batches of skim milk, each divided into 3 equal parts, were microfiltered. For single-stage concentration-DF modes with $0.1-\mu \mathrm{m}$ SW membrane, one batch of skim milk was divided into 3 equal parts of about $280 \mathrm{~L}$. Total recirculation and concentration DF experiments were carried out in triplicate.

\section{MF System}

The MF system (model 393, Tetra Pak Filtration Systems, Champlin, MN) was the same as described by Tremblay-Marchand et al. (2016). Briefly, it was equipped with 2 feed pumps (model LKHP-10, Alfa Laval, and model H-25, Wanner Engineering Inc., Minneapolis, MN) and 1 recirculation pump (model LKHP-10, Alfa Laval). Flow rates were measured with electromagnetic flow meters (model SM2001, IFM Electronic, Malvern, PA). A pressure sensor (model PF265x, IFM Electronic) measured the inlet and outlet retentate pressures as well as permeate pressure at the outlet. The system is composed of 3 stages with 3 filtration loops but this study used only one stage with 1 or $2 \mathrm{SW}$ MF membranes installed in series in the loop. The 0.1- or $0.2-\mu \mathrm{m}$ pore diameter SW MF membranes (models V0.1-2B-3838 and V0.2B-3838, Synder Filtration, Vacaville, CA) with surface areas of 6.69 and 7.06 $\mathrm{m}^{2}$, respectively, were mounted horizontally. The SW membrane elements had feed spacers of $0.79 \mathrm{~mm}$ (31 mils), diameter of $9.65 \mathrm{~cm}$ (3.8 inches), and a length of $96.52 \mathrm{~cm}$ (38 inches). The average cross-flow velocity was estimated between 0.9 to $1.12 \mathrm{~m} / \mathrm{s}$ for cross-flow rates at $5.9 \mathrm{~m}^{3} / \mathrm{h}$ in the element, as determined according to the scroll-end area method (Johnson, 2013).

\section{Operational Modes}

Total Recirculation Mode. In total recirculation mode, the MF system was operated in a closed loop 
because retentate and permeate were both recycled into the feed tank. Experiments were carried out with one 0.1 - or $0.2-\mu \mathrm{m} \mathrm{SW}$ membranes at 3 different TMP $(89.6,106.9$, and $124.1 \mathrm{kPa})$ to determine the optimal operational conditions (i.e., TMP) for concentration mode. Prior to processing, SW MF membranes were rinsed and cleaned and a pure water permeate flux was measured with tap water at $50^{\circ} \mathrm{C}$ as described in Tremblay-Marchand et al. (2016). The membranes were then conditioned, also according to the protocol detailed in Tremblay-Marchand et al. (2016). Before total recirculation mode, skim milk was heated at $50^{\circ} \mathrm{C}$ for $60 \mathrm{~min}$ to reach protein and mineral balance (Jimenez-Lopez et al., 2008). Thereafter, skim milk was transferred into the MF system and a flush of $100 \mathrm{~kg}$ of skim milk was carried out as described by Tremblay-Marchand et al. (2016) to evacuate the residual water from the system. Following the removal of all milk and rinse water, skim milk was added to the feed tank, allowing for the dead volume, to obtain a final volume of $115 \mathrm{~L}$. Skim milk was recirculated for $30 \mathrm{~min}$ to stabilize flow rates and pressures and each TMP level was maintained for 45 min. Permeate flux was measured in triplicate every 15 min for each TMP and samples of retentate and permeate were collected at the end of the 45 min period for each TMP and stored at $4{ }^{\circ} \mathrm{C}$ until analyzed. At the end of the experiment, the MF system was drained and a fouled membrane water flux with tap water at $50^{\circ} \mathrm{C}$ was measured. After every experiment, the cleaning procedure described by Tremblay-Marchand et al. (2016) was performed and a cleaned membrane water flux was measured to confirm that membrane performance was recovered. This water flux had to differ from the initial water flux by less than $10 \%$ to demonstrate efficient cleaning.

Concentration DF of Skim Milk. For concentration DF experiments, the rinsing, cleaning, conditioning, flush, and filling steps were the same as described in the total recirculation experiments, except that 260 L of milk was used. Single-stage concentration and DF were both performed at $50^{\circ} \mathrm{C}$ at a TMP of $124.1 \mathrm{kPa}$ with two $0.1-\mu \mathrm{m}$ SW membranes installed in series in the loop, the optimal TMP and membrane pore size diameter determined after total recirculation experiments. Skim milk was concentrated to a CF of $3.0 \times$, followed by 2 sequential $\mathrm{DF}$ of 2 diavolumes each and re-concentration to a $\mathrm{CF}$ of $3.0 \times$, as described by Tremblay-Marchand et al. (2016). Initial skim milk, retentate, and permeate samples from concentration (CF of 1.5, 2.0, 2.5, and $3.0 \times)$ and $\mathrm{DF}(\mathrm{DF} \# 1$ and \#2) experiments were collected and stored at $4^{\circ} \mathrm{C}$ until analyzed. Finally, the MF system was drained and cleaned as described in Tremblay-Marchand et al. (2016).

\section{Membrane Fouling Characterization}

The resistance-in-series model was applied to evaluate membrane fouling at the end of concentration-DF experiments. Membrane resistance $\left(\mathbf{R}_{\mathrm{m}}\right)$, reversible resistance $\left(\mathbf{R}_{\text {rev }}\right)$, irreversible resistance $\left(\mathbf{R}_{\text {irr }}\right)$, and total resistance $\left(\mathbf{R}_{\text {tot }}\right)$ were determined according equations given by Bae and Tak (2005). The $\mathrm{R}_{\mathrm{m}}$ is the membrane hydraulic resistance. The $\mathrm{R}_{\text {rev }}$ represents fouling induced by the concentration polarization phenomenon, which can be removed by a rinse step. The $R_{\text {irr }}$ is related to protein adsorption on the membrane surface and pore blocking, which can be eliminated by a cleaning-in-place protocol (Bae and Tak, 2005; Ben Hassan et al., 2013).

\section{Chemical Analysis}

Composition of Milk, Permeate, and Retentate Samples. Nitrogen content [total nitrogen (TN), noncasein nitrogen (NCN), and NPN] in samples was determined by the Kjeldahl method (AOAC International, 2000; methods 991.20, 998.05, and 991.21, respectively). Total protein content was calculated by multiplying the TN by a factor of 6.38 . True protein was determined as $(\mathrm{TN}-\mathrm{NPN}) \times 6.38, \mathrm{CN}$ as $(\mathrm{TN}-$ $\mathrm{NCN}) \times 6.38$ and $\mathrm{SP}$ as $(\mathrm{NCN}-\mathrm{NPN}) \times 6.38$. Serum protein removal (\%) from skim milk was determined by dividing SP $(\mathrm{kg})$ in composite permeate by $\mathrm{SP}(\mathrm{kg})$ in skim milk and multiplying by $100.0 \%$, using the Kjeldahl nitrogen analyses above and recorded processing data. Total solids in samples were measured using the forced-air oven drying method (AOAC International, 2000; method 990.20). The rejection coefficients of CN and SP were measured from CN and SP content (\%) in the retentates and permeates as described in TremblayMarchand et al. (2016).

Protein Profile. The protein profiles of permeates collected during total recirculation experiments with the 0.1 - and $0.2-\mu \mathrm{m}$ SW membranes were determined by SDS-PAGE analysis. Analyses were performed using Bio-Rad mini-protean TGX precast gels (Bio-Rad Laboratories, Hercules, CA) containing $12.5 \%$ polyacrylamide. Permeate samples were diluted and solubilized in deionized water to obtain a protein content of 2.5 to $3.0 \mathrm{mg}$. Ten microliters of this solution was diluted with one-third volume of buffer $(20 \mu \mathrm{L})$ containing 0.5 $M$ Tris-HCl (pH 6.8; $12.5 \% \mathrm{vol} / \mathrm{vol}), 10 \%$ SDS $(20 \%$ $\mathrm{vol} / \mathrm{vol}), 20 \%$ glycerol $(25 \% \mathrm{vol} / \mathrm{vol}), 0.5 \%$ bromophenol blue tracking dye $(2 \% \mathrm{vol} / \mathrm{vol}), \beta$-mercaptoethanol $(5 \% \mathrm{vol} / \mathrm{vol})$, and deionized water $(35.5 \% \mathrm{vol} / \mathrm{vol})$. Samples were heated to $100^{\circ} \mathrm{C}$ in a water bath for 5 min and loaded on the gel. Then, the gels were run, stained, and destained according to the manufacturer's 
instructions, with changes detailed by Garfin (1990) and Hames (1990). Precision Plus Protein Dual Color (Bio-Rad Laboratories) standards were used to identify the bands obtained. The gels were scanned with the GS 800 Densitometer using Quantity One 1-D Analysis Software (Bio-Rad Laboratories Inc.) to obtain relative protein proportions within each sample.

\section{Energy Consumption}

Energy consumption was determined according to the method of Tremblay-Marchand et al. (2016), by recording current voltage (U) and intensity (I) data in real time. Energy consumption, expressed as $\mathrm{kWh} / \mathrm{kg}$ of permeate collected, was obtained by calculating the power requirement $(\mathrm{P})$ during $\mathrm{MF}$ experiments. Equation [1] was used to calculate the real power consumption $(\mathrm{P})$ of the 3 -phase motors:

$$
\mathrm{P}=\sqrt{ } 3 \times \mathrm{U} \times \mathrm{I} \times \eta
$$

where $\mathrm{P}$ is the real power consumption $(\mathrm{W}), \mathrm{U}$ is the current voltage $(\mathrm{V}), \mathrm{I}$ is the intensity $(\mathrm{A})$, and $\eta$ is the power factor and is assumed to be 0.65 , as reported in Tremblay-Marchand et al. (2016). Equation [2] was applied to convert real power consumption to energy consumption:

$$
\text { energy consumption }=\frac{\mathrm{P} \times \text { time }}{1,000},
$$

where $\mathrm{P}$ is the real power consumption $(\mathrm{W})$ and time represents the operating time of the pumps (h). From the mean flux values, the time required to remove $1 \mathrm{~kg}$ of permeate with the membrane surface area present in the system was calculated, subsequently converting the real power consumption into energy quantity units per amount of permeate collected $(\mathrm{kWh} / \mathrm{kg}$ of permeate collected). It was assumed that the MF system had ideal thermal insulation and that heat loss was equivalent to heat gain caused by the friction of the milk in the system; therefore, only the mechanical energy has been quantified.

\section{Statistical Analysis}

Significant differences were analyzed by ANOVA and polynomial contrasts with 10.0 JMP (SAS Institute Inc., Cary, NC). Significant differences were studied by means comparisons using the Tukey test $(P<0.05)$.

\section{RESULTS}

\section{Comparative Performance of 0.1- $\mu$ m and 0.2- $\mu \mathrm{m}$ SW MF Membranes}

Figure 1 reports the change in permeate flux $(\mathrm{kg} /$ $\left.\mathrm{h} \cdot \mathrm{m}^{2}\right)$ as a function of TMP $(\mathrm{kPa})$ for the 0.1- and $0.2-\mu \mathrm{m}$ SW membranes during MF of pasteurized skim milk in total recirculation mode at $50^{\circ} \mathrm{C}$. For the 2 membrane pore sizes studied, mean permeate flux increased similarly $(P>0.05)$ with increasing TMP (from 30.43 to $41.60 \mathrm{~kg} / \mathrm{h} \cdot \mathrm{m}^{2}$ for the $0.1-\mu \mathrm{m} \mathrm{SW}$ membrane and from 36.55 to $45.31 \mathrm{~kg} / \mathrm{h} \cdot \mathrm{m}^{2}$ for the $0.2-\mu \mathrm{m}$ SW membrane). For each TMP level, no significant difference $(P>0.05)$ was observed in flux values between the 2 membranes. However, water flux characterization (data not shown) of the $0.2-\mu \mathrm{m}$ SW membrane had higher mean fluxes (201.66 to $292.93 \mathrm{~kg} / \mathrm{h} \cdot \mathrm{m}^{2}$ ) than the $0.1-\mu \mathrm{m}$ SW membrane (161.47 to $195.04 \mathrm{~kg} / \mathrm{h} \cdot \mathrm{m}^{2}$ ) over a similar TMP range. Because no limiting flux was observed for the selected TMP levels, the highest TMP value, $124.1 \mathrm{kPa}$, was chosen for concentration and $\mathrm{DF}$ experiments.

Table 1 shows the changes in composition of skim milk and MF permeates and retentates produced in total recirculation mode at different TMP during $\mathrm{MF}$ at $50^{\circ} \mathrm{C}$ with $\mathrm{SW}$ membranes. Our results show that rejection of $\mathrm{CN}$ and $\mathrm{SP}$ was similar $(P>0.05)$, whatever the SW membrane used and TMP applied. The CN rejection coefficient was slightly higher for the $0.1-\mu \mathrm{m}$ SW membrane compared the $0.2-\mu \mathrm{m}$ SW

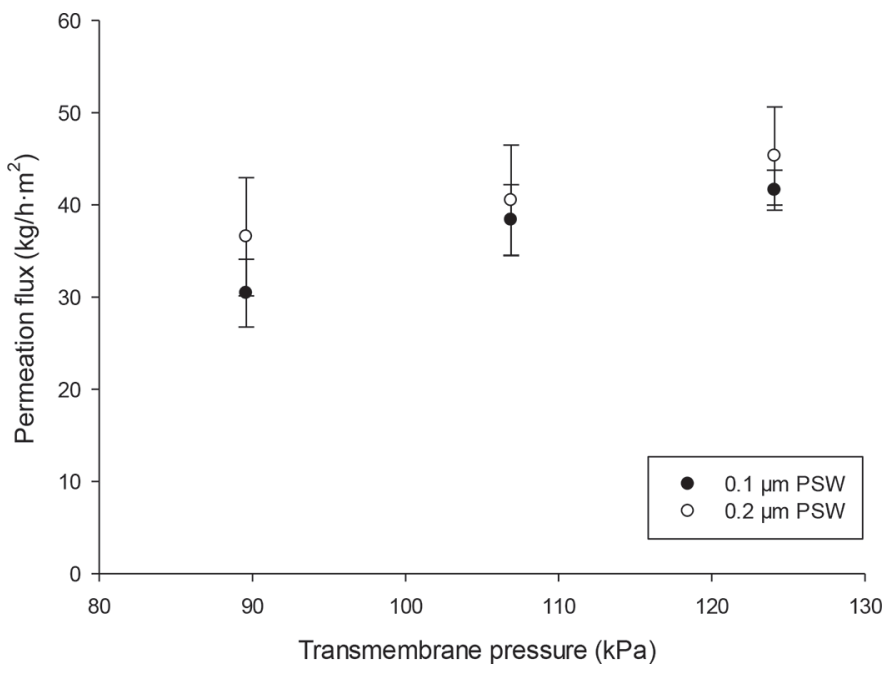

Figure 1. Permeate fluxes at different transmembrane pressure during microfiltration (MF) of pasteurized skim milk (PSW; temperature $=50^{\circ} \mathrm{C}$ ) with 0.1 - and $0.2-\mu \mathrm{m}$ spiral-wound (SW) membrane. Error bars indicate SD of triplicate determinations. 
Table 1. Mean composition ${ }^{1}$ (\% by weight) of skim milk and microfiltration (MF) permeate and retentate produced at different transmembrane pressures (TMP) during a $\mathrm{MF}$ at $50^{\circ} \mathrm{C}^{2}$

\begin{tabular}{|c|c|c|c|c|c|c|c|c|c|c|c|c|c|}
\hline Membrane & $\begin{array}{l}\text { TMP } \\
(\mathrm{kPa})\end{array}$ & Sample & $\begin{array}{l}\text { TN } \\
(\%)\end{array}$ & $\begin{array}{c}\text { NCN } \\
(\%)\end{array}$ & $\begin{array}{c}\text { NPN } \\
(\%)\end{array}$ & $\begin{array}{l}\mathrm{TP} \\
(\%)\end{array}$ & $\begin{array}{l}\mathrm{CN} \\
(\%)\end{array}$ & $\begin{array}{l}\text { SP } \\
(\%)\end{array}$ & $\mathrm{CN} \% \mathrm{TP}$ & $\begin{array}{c}\mathrm{CN} \\
\text { rejection } \\
\text { coefficient }\end{array}$ & $\begin{array}{c}\text { SP } \\
\text { rejection } \\
\text { coefficient }\end{array}$ & $\begin{array}{c}\text { Solids } \\
(\%)\end{array}$ & $\begin{array}{c}\text { SP removal } \\
\text { rate } \\
\left(\mathrm{kg} / \mathrm{h} \cdot \mathrm{m}^{2}\right)\end{array}$ \\
\hline \multirow[t]{4}{*}{$0.1-\mu \mathrm{m}$ SW } & \multirow{2}{*}{$\overline{90}$} & Skim milk & 3.36 & 0.66 & 0.14 & 3.23 & 2.71 & 0.52 & 83.86 & - & \multirow{2}{*}{$0 . \overline{7} 2^{\mathrm{ab}}$} & 8.79 & \multirow{2}{*}{${\overline{0.05^{\mathrm{d}}}}^{\mathrm{d}}$} \\
\hline & & Permeate & $0.36^{\mathrm{b}}$ & $0.32^{\mathrm{b}}$ & $0.15^{\mathrm{ab}}$ & $0.21^{\mathrm{b}}$ & $0.04^{\mathrm{b}}$ & $0.17^{\mathrm{c}}$ & $21.01^{\mathrm{c}}$ & $0.99^{\mathrm{a}}$ & & $5.70^{\mathrm{abc}}$ & \\
\hline & \multirow[t]{2}{*}{107} & Retentate & $4.46^{\mathrm{a}}$ & $0.72^{\mathrm{ab}}$ & $0.13^{\mathrm{b}}$ & $4.34^{\mathrm{a}}$ & $3.74^{\mathrm{a}}$ & $0.59^{\mathrm{ab}}$ & $86.28^{\mathrm{a}}$ & \multirow[t]{2}{*}{$0.99^{\mathrm{a}}$} & \multirow[t]{2}{*}{$0.72^{\mathrm{ab}}$} & $9.83^{\mathrm{a}}$ & \multirow[t]{2}{*}{$0.06^{\mathrm{c}}$} \\
\hline & & Permeate & $0.38^{\mathrm{ab}}$ & $0.32^{\mathrm{b}}$ & $0.15^{\mathrm{ab}}$ & $0.22^{\mathrm{b}}$ & $0.06^{\mathrm{b}}$ & $0.17^{\mathrm{c}}$ & $26.29^{\mathrm{bc}}$ & & & $5.67^{\mathrm{abc}}$ & \\
\hline \multirow[t]{7}{*}{$0.2-\mu \mathrm{m}$ SW } & \multirow{3}{*}{$\overline{90}$} & Skim milk & 3.19 & 0.59 & 0.14 & 3.05 & 2.60 & 0.45 & 85.28 & - & - & 8.43 & \multirow{3}{*}{$0.08^{\mathrm{b}}$} \\
\hline & & Retentate & $3.50^{\mathrm{bc}}$ & $0.65^{\mathrm{ab}}$ & $0.13^{\mathrm{b}}$ & $3.37^{\mathrm{bc}}$ & $2.86^{\mathrm{bc}}$ & $0.51^{\mathrm{ab}}$ & $84.74^{\mathrm{a}}$ & \multirow[t]{2}{*}{$0.93^{\mathrm{ab}}$} & \multirow[t]{2}{*}{$0.56^{\mathrm{b}}$} & $8.93^{\mathrm{c}}$ & \\
\hline & & Permeate & $0.58^{\mathrm{ab}}$ & $0.38^{\mathrm{b}}$ & $0.15^{\mathrm{ab}}$ & $0.43^{\mathrm{ab}}$ & $0.20^{\mathrm{ab}}$ & $0.23^{\mathrm{abc}}$ & $47.50^{\mathrm{abc}}$ & & & $5.65^{\mathrm{abc}}$ & \\
\hline & \multirow[t]{2}{*}{107} & Retentate & $3.63^{\mathrm{bc}}$ & $0.67^{\mathrm{ab}}$ & $0.13^{\mathrm{b}}$ & $3.50^{\mathrm{bc}}$ & $2.95^{\mathrm{bc}}$ & $0.54^{\mathrm{ab}}$ & $84.44^{\mathrm{a}}$ & \multirow[t]{2}{*}{$0.90^{\mathrm{ab}}$} & \multirow[t]{2}{*}{$0.61^{\mathrm{ab}}$} & $8.91^{\mathrm{c}}$ & \multirow[t]{2}{*}{$0.09^{\mathrm{a}}$} \\
\hline & & Permeate & $0.64^{\mathrm{ab}}$ & $0.35^{\mathrm{b}}$ & $0.14^{\mathrm{ab}}$ & $0.50^{\mathrm{ab}}$ & $0.29^{\mathrm{ab}}$ & $0.21^{\mathrm{bc}}$ & $57.67^{\mathrm{ab}}$ & & & $5.59^{\mathrm{bc}}$ & \\
\hline & \multirow[t]{2}{*}{124} & Retentate & $3.72^{\mathrm{bc}}$ & $0.62^{\mathrm{b}}$ & $0.13^{\mathrm{b}}$ & $3.59^{\mathrm{bc}}$ & $3.10^{\mathrm{bc}}$ & $0.49^{\mathrm{b}}$ & $86.33^{\mathrm{a}}$ & \multirow[t]{2}{*}{$0.87^{\mathrm{b}}$} & \multirow[t]{2}{*}{$0.59^{\mathrm{b}}$} & $9.25^{\mathrm{bc}}$ & \multirow[t]{2}{*}{$0.09^{\mathrm{a}}$} \\
\hline & & Permeate & $0.73^{\mathrm{a}}$ & $0.34^{\mathrm{b}}$ & $0.14^{\mathrm{b}}$ & $0.59^{\mathrm{a}}$ & $0.39^{\mathrm{a}}$ & $0.20^{\mathrm{c}}$ & $66.12^{\mathrm{a}}$ & & & $5.53^{\mathrm{c}}$ & \\
\hline
\end{tabular}

\footnotetext{
$\overline{\mathrm{a}-\mathrm{d}}$ Values in the same column without a common superscript are significantly different (Tukey, $P<0.05)$. Permeates are compared with permeates, and retentates are compared with retentates.

${ }^{1}$ Based on triplicate experiments.

${ }^{2} \mathrm{TN}=$ total nitrogen $\times 6.38 ; \mathrm{NCN}=$ noncasein nitrogen $\times 6.38 ; \mathrm{NPN}=$ nonprotein nitrogen $\times 6.38 ; \mathrm{TP}=$ true protein $(\mathrm{TN}-\mathrm{NPN}) ; \mathrm{CN}=$ caseins $(\mathrm{TN}-\mathrm{NCN}) ; \mathrm{SP}=$ serum proteins $(\mathrm{TP}-\mathrm{CN}) ; \mathrm{CN} \% \mathrm{TP}=$ caseins as percentage of true protein; $\mathrm{SW}=$ spiral wound.
}

membrane (0.99 vs. 0.87-0.93). However, these differences were not significant $(P>0.05)$ between the 2 SW membranes, except at the highest TMP level (124 $\mathrm{kPa}$ ). The SP rejection coefficients were slightly higher for the $0.1 \mu \mathrm{m}$ pore diameter compared with the 0.2 $\mu \mathrm{m}$ pore diameter (rejection coefficients of 0.72 to 0.78 and 0.56 to 0.61 , respectively), but the difference was statistically significant $(P<0.05)$ only at a TMP of $124 \mathrm{kPa}$. Furthermore, the SP removal rate was higher for the 0.2- $\mu \mathrm{m}$ SW membrane compared with the 0.1$\mu \mathrm{m}$ SW membrane, which resulted in more SP fraction removed for the $0.2-\mu \mathrm{m} \mathrm{SW}$ membrane $(P<0.05)$ with a maximum of $0.09 \mathrm{~kg} / \mathrm{h} \cdot \mathrm{m}^{2}$, compared with $0.06 \mathrm{~kg} /$ $\mathrm{h} \cdot \mathrm{m}^{2}$ for the $0.1-\mu \mathrm{m}$ SW membrane.

For all TMP levels, permeates from the $0.2-\mu \mathrm{m}$ SW membrane were more turbid and produced more intense CN bands on SDS-PAGE gels compared with the permeates from the 0.1- $\mu \mathrm{m}$ SW membrane (Figure 2). Considering the loss of $\mathrm{CN}$ observed with the $0.2-\mu \mathrm{m}$ SW membrane, the 0.1- $\mu \mathrm{m}$ SW membrane was chosen for the remainder of the study.

\section{Performance of 0.1- $\mu m$ SW Membrane During Concentration and DF of Skim Milk}

Figure 3 shows permeate flux changes as a function of permeate volume collected. We observed that after cleaning the system, total flux decline reached $62.0 \%$ after initial concentration to a CF of $3.0 \times$ and 2 sequential DF. Both DF sequences allowed initial flux to increase (48.51 and $54.18 \mathrm{~kg} / \mathrm{m}^{2} \cdot \mathrm{h}$ for DF \#1 and $\mathrm{DF} \# 2$, respectively) for the first concentration step $\left(36.99 \mathrm{~kg} / \mathrm{m}^{2} \cdot \mathrm{h}\right)$, whereas the flux decline after each step was similar $(38.15 \%$ for initial concentration, $34.18 \%$ for the first DF, and $34.39 \%$ for the second). As shown in Figure 3, during concentration of skim milk by $\mathrm{MF}$ at $50^{\circ} \mathrm{C}$, the largest flux decline for the $0.1-\mu \mathrm{m}$ SW membrane occurred during the second DF.

Permeate and retentate compositions during the concentration and sequential DF of skim milk are reported in Table 2. Casein rejection was similar $(P>0.05)$ and ranged from 0.99 to 1.00 whatever the $\mathrm{CF}$ and DF stage, indicating complete retention of $\mathrm{CN}$ in $\mathrm{MF}$ retentates. No significant differences $(P>0.05)$ were observed in $\mathrm{SP}$ rejection as $\mathrm{CF}$ was increased from $2.0 \times$ to $3.0 \times(0.75$ vs. 0.79 , respectively), and during $\mathrm{DF}$ steps (0.80 to 0.92). During the concentration and DF, the SP removal rate decreased $(P<0.05)$ from 0.06 to $0.02 \mathrm{~kg} / \mathrm{h} \cdot \mathrm{m}^{2}$ until the end of CF $3.0 \times$ and DF \#2.

The data reported in Table 3 compares the overall performance characteristics of the $0.1-\mu \mathrm{m}$ SW membrane with that of a $0.1-\mu \mathrm{m}$ GP membrane (already published by Tremblay-Marchand et al., 2016). The average permeate fluxes were significantly higher $(P<$ $0.05)$ for the 0.1- $\mu \mathrm{m}$ GP membrane compared with the $0.1-\mu \mathrm{m}$ SW membrane (approximately $3.5 \times$ higher), whatever the stage (concentration, DF \#1, or DF \#2). Similar CN rejection coefficients (0.99) but higher SP rejection coefficients (0.79 vs. 0.49 ) were obtained for the $0.1-\mu \mathrm{m}$ SW membrane compared with the GP 

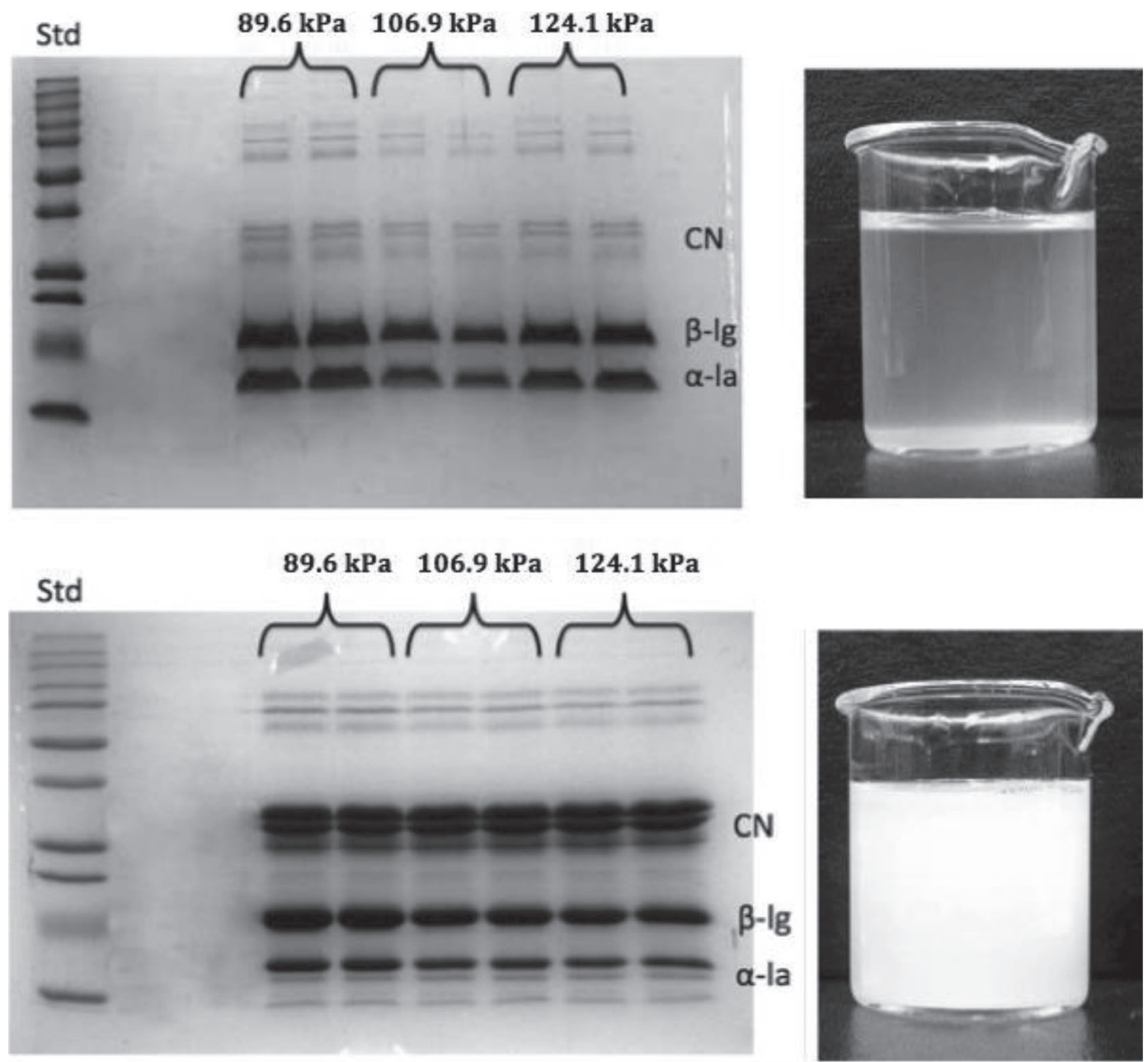

Figure 2. Sodium dodecyl sulfate-PAGE permeate separation and appearance of permeates from 0.1- $\mu \mathrm{m}$ (top) and $0.2-\mu \mathrm{m}$ (bottom) spiralwound membranes. Std $=$ standard. Error bars indicate SD of triplicate determinations.

membrane. Thus, a significantly higher SP removal rate $(P<0.05)$ was obtained for the GP membrane $(0.09$ vs. $\left.0.02 \mathrm{~kg} / \mathrm{h} \cdot \mathrm{m}^{2}\right)$.

Energy consumption by the 0.1- $\mu \mathrm{m}$ SW membrane was 5 -fold lower, on average. For the $0.1-\mu \mathrm{m}$ SW membrane, energy consumption was highest at a $\mathrm{CF}$ of $3.0 \times$ $(0.024 \mathrm{kWh} / \mathrm{kg}$ of permeate collected) and was significantly higher $(P<0.05)$ than the other conditions, but decreased its lowest value $(0.015 \mathrm{kWh} / \mathrm{kg}$ of permeate collected) during DF \#2. The characterization of hydraulic resistance of the $0.1-\mu \mathrm{m}$ SW membrane revealed that the $R_{\text {irr }}$ resulting from membrane fouling accounted for $26 \%$ of the $\mathrm{R}_{\text {tot }}\left(0.81 \times 10^{13} \mathrm{~m}^{-1}\right.$ vs. 3.15 $\times 10^{13} \mathrm{~m}^{-1}$ ) of the system during MF/DF of skim milk. However, no significant differences $(P>0.05)$ were found between $R_{m}, R_{\text {rev }}$, and $R_{\text {irr }}$. The $R_{\text {irr }}$ was significantly higher $(P<0.05)$ for the SW membrane than GP membrane $\left(0.81 \mathrm{E}+13\right.$ vs. $\left.0.11 \mathrm{E}+13 \mathrm{~m}^{-1}\right)$, as well as
$\mathrm{R}_{\text {rev }}\left(1.87 \mathrm{E}+13\right.$ vs. $\left.0.18 \mathrm{E}+13 \mathrm{~m}^{-1}\right)$. Globally, $\mathrm{R}_{\text {tot }}$ was about 5 times higher $(P<0.05)$ for the GP membrane than for the SW membrane.

\section{DISCUSSION}

\section{Effect of SW Membrane Pore Size}

Despite different water permeability characteristics, the SW membrane pore size $(0.1$ vs. $0.2 \mu \mathrm{m})$ had no effect $(P>0.05)$ on permeate fluxes. The relationship between TMP and permeate flux in total recirculation mode was consistent with the previous work of Tremblay-Marchand et al. (2016) and the permeate fluxes remained constant even after $3 \mathrm{~h}$ of continuous filtration.

Selecting a $0.1-\mu \mathrm{m}$ pore size seems easily justifiable based on our results using total recirculation mode. Us- 


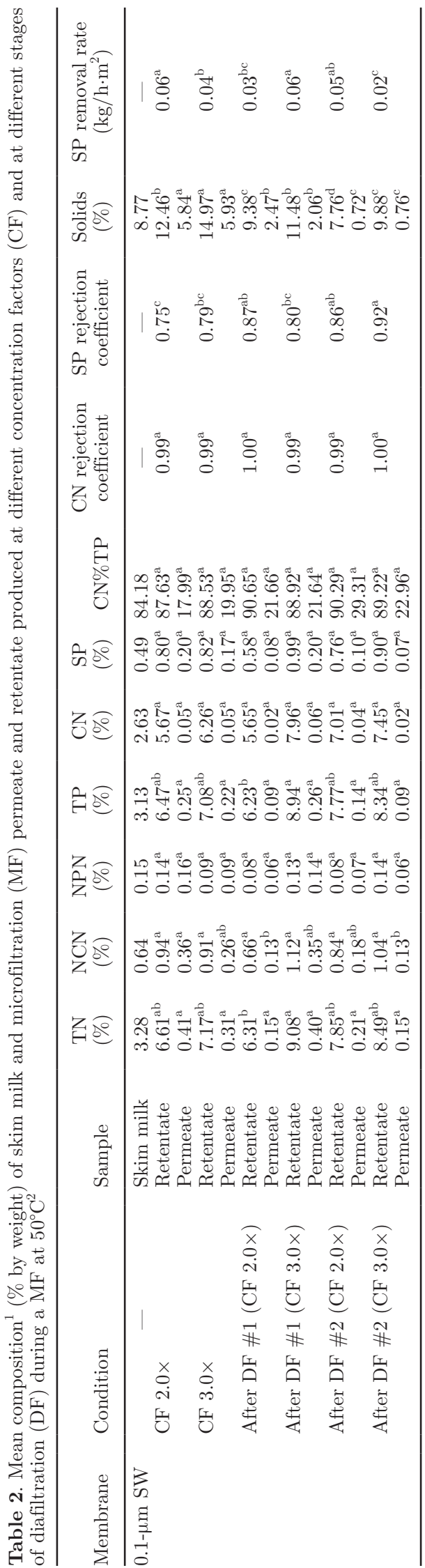

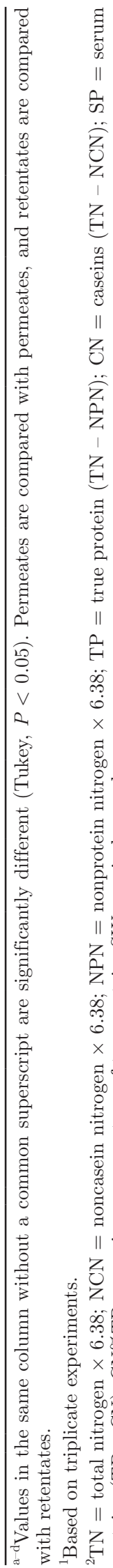

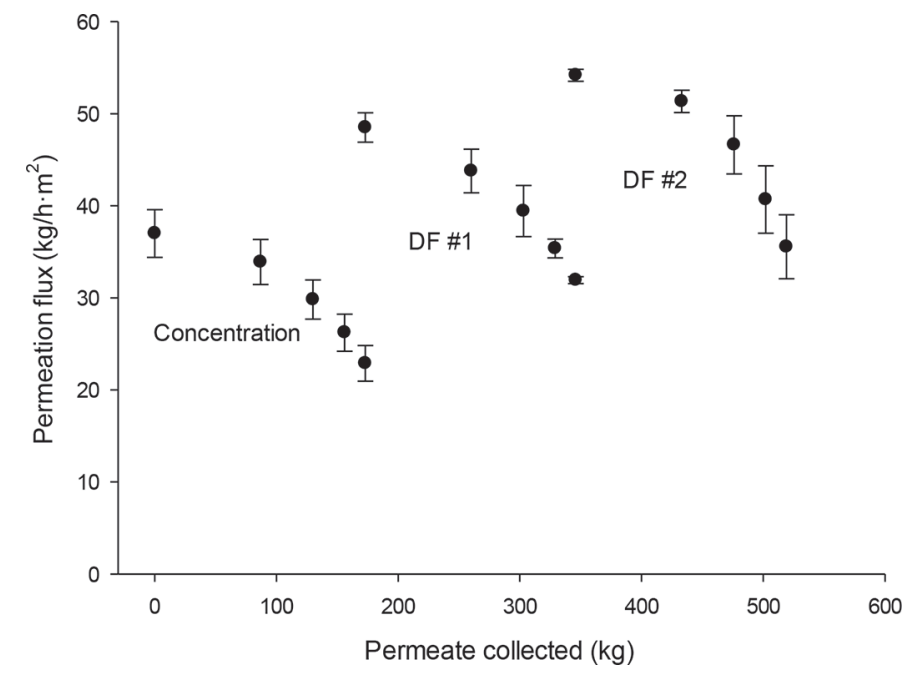

Figure 3. Permeate fluxes as a function of the amount of permeate collected by microfiltration (MF) of pasteurized skim milk (temperature $=50^{\circ} \mathrm{C}$ ) with a $0.1-\mu \mathrm{m}$ spiral-wound (SW) membrane after an initial concentration (concentration factor of $3.0 \times$ ), and 2 subsequent diafiltrations (DF) and re-concentration to a concentration factor of $3.0 \times$. Error bars indicate SD of triplicate determinations.

ing the $0.2-\mu \mathrm{m}$ SW membrane resulted in a decrease in $\mathrm{CN}$ in the retentate when TMP was increased. According to Govindasamy-Lucey et al. (2007), 0.2- $\mu \mathrm{m} \mathrm{SW}$ MF membranes can be used to produce $\mathrm{CN}$-enriched retentate to standardize milk for manufacturing pizza cheese; however, we found that the $0.1-\mu \mathrm{m}$ pore size SW membrane better separates CN from milk. Our observations on SP rejection, data are consistent with Zulewska et al. (2009) who also found that the rejection of SP is higher $(P<0.05)$ for the SW membrane (38.62\% SP removed) than for the ceramic membrane (61.04\% SP removed). Beckman et al. (2010) compared ceramic and SW MF membranes with different pore size diameters and found that fouling material (cake layer) controlled the passage of SP through a $0.3-\mu \mathrm{m}$ PVDF SW membrane because a total SP reduction of only $70.3 \%$ was achieved after a single-stage concentration to a CF of $3.0 \times$ and 2 sequential DF. The fouling obtained in our experiments did not have as much effect on the fluxes with 0.1- and 0.2- $\mu \mathrm{m}$ SW membrane pore sizes.

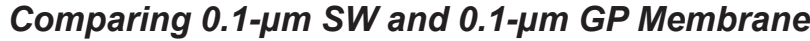 Performance During Skim Milk Concentration and DF}

The difference in permeate flux between the 2 membranes can be related to the membrane structure, porosity, type of material, and effective thickness (Hu et al., 2015). Zulewska et al. (2009) demonstrated that large differences existed for MF concentration tests at $50^{\circ} \mathrm{C}$ with different membranes. Also, the higher perme- 
ate flux values for the 0.1- $\mu \mathrm{m}$ GP membrane compared with the $0.1-\mu \mathrm{m}$ SW membrane can be attributed to protein accumulation at the membrane surface, resulting from the high cross-flow velocities of milk in the membrane (i.e., 5.0 to $7.0 \mathrm{~m} / \mathrm{s}$ for GP membranes vs. 1.0 to $1.2 \mathrm{~m} / \mathrm{s}$ for SW membranes; Saboya and Maubois 2000; Lawrence et al., 2008). In fact, as described by Cheryan (1998), low TMP and high cross-flow velocity reduce the risk of gel layer formation. However, the concentration and DF tests were carried out at a higher TMP for the GP membrane (151.7 vs. $124.1 \mathrm{kPa}$ for the PWS membrane), which suggests that it is the turbulent regimen caused by the high cross-flow velocity that has the greatest effect on fouling and produces the higher permeate fluxes.

Conversely, with a similar pore diameter of 0.1 $\mu \mathrm{m}$, the GP and SW MF membranes had similar CN rejection coefficients $(P>0.05)$ with almost perfect retention. The higher $\mathrm{SP}$ rejection observed with the $0.1-\mu \mathrm{m}$ SW membrane $(P<0.05)$ results, most importantly, from the lower retentate cross-flow velocity in SW elements, which favors membrane fouling by milk constituents and is demonstrated in Table 3 by higher hydraulic resistance values for the $0.1-\mu \mathrm{m}$ SW membrane (Saboya and Maubois, 2000).

Our results demonstrate that the SW membrane has higher resistances $(P<0.05)$ for all categories of resistances calculated because of the effect of rinsing and cleaning on these MF membranes. The higher $R_{\text {irr }}$ of the PVDF SW membrane, compared with the GP membrane, is related to the fact that PVDF membrane material can rapidly become fouled by adsorbed hydrophobic proteins from contact with milk (Tong et al., 1988; Bowen and Gan, 1991). The hydrophilic nature of ceramic membranes results in lower protein adsorption to the membrane (Baruah et al., 2006). However, some key operating conditions can reduce the risk of gel layer formation: low TMP, high cross-flow velocity, and low CF (Cheryan, 1998). With a higher cross-flow velocity (6.0-7.0 vs. $1.12 \mathrm{~m} / \mathrm{s})$, similar TMP and the same $\mathrm{CF}$ as the $0.1-\mu \mathrm{m}$ SW membrane, ceramic membranes promote less overall fouling. As mentioned previously, the TMP could have been higher for the $0.1-\mu \mathrm{m}$ SW membrane to improve permeate flux. However, the choice of a higher TMP for this membrane could also increase the rate of fouling and reach the critical flux (Hu et al., 2015). Finally, the effect of feed spacer size and geometry was not investigated in the present study, but it may represent another approach to optimize flux values and $\mathrm{SP}$ separation.

\section{Techno-Economic Assessment of MF Membranes}

Although we compared several performance indicators in this study, there is great interest in the economics of using ceramic and polymeric membranes because there are important differences in capital investment and operation cost.

Table 3. Comparison ${ }^{1}$ of the overall performance of $0.1-\mu \mathrm{m}$ spiral-wound (SW) membrane with a $0.1-\mu$ m graded permeability (GP) membrane during a microfiltration $(\mathrm{MF})$ at $50^{\circ} \mathrm{C}$ including concentration [concentration factor $(\mathrm{CF})$ of $3.0 \times$ ] and 2 sequential diafiltrations $(\mathrm{DF})^{2}$

\begin{tabular}{|c|c|c|c|}
\hline Item $^{3}$ & & \multicolumn{2}{|c|}{ Membrane } \\
\hline Flux & $\begin{array}{l}\text { At CF } 3.0 \times\left(\mathrm{kg} / \mathrm{h} \cdot \mathrm{m}^{2}\right) \\
\text { After DF \#1, CF } 3.0 \times\left(\mathrm{kg} / \mathrm{h} \cdot \mathrm{m}^{2}\right) \\
\text { After DF \#2,CF } 3.0 \times\left(\mathrm{kg} / \mathrm{h} \cdot \mathrm{m}^{2}\right) \\
\text { Flux decline (from CF } 1.0 \text { to } 3.0 \times ; \%)\end{array}$ & $\begin{array}{l}22.88^{\mathrm{b}} \\
31.93^{\mathrm{b}} \\
35.55^{\mathrm{b}} \\
38.15^{\mathrm{a}}\end{array}$ & $\begin{array}{r}90.01^{\mathrm{a}} \\
115.42^{\mathrm{a}} \\
139.30^{\mathrm{a}} \\
39.47^{\mathrm{a}}\end{array}$ \\
\hline Energy efficiency & $\begin{array}{l}\text { Energy consumption (CF } 3.0 \times ; \mathrm{kWh} / \mathrm{kg} \text { of permeate collected) } \\
\text { Energy consumption (after DF } \# 2-\mathrm{CF} 3.0 \times ; \mathrm{kWh} / \mathrm{kg} \text { of permeate collected) }\end{array}$ & $\begin{array}{l}0.024^{\mathrm{b}} \\
0.015^{\mathrm{b}}\end{array}$ & $\begin{array}{l}0.143^{\mathrm{a}} \\
0.077^{\mathrm{a}}\end{array}$ \\
\hline Hydraulic resistance & $\begin{array}{l}\mathrm{R}_{\mathrm{m}}\left(\mathrm{m}^{-1}\right) \\
\mathrm{R}_{\text {irr }}\left(\mathrm{m}^{-1}\right) \\
\mathrm{R}_{\text {rev }}\left(\mathrm{m}^{-1}\right) \\
\mathrm{R}_{\text {tot }}\left(\mathrm{m}^{-1}\right)\end{array}$ & $\begin{array}{l}0.47 \mathrm{E}+13^{\mathrm{b}} \\
0.81 \mathrm{E}+13^{\mathrm{b}} \\
1.87 \mathrm{E}+13^{\mathrm{a}} \\
3.15 \mathrm{E}+13^{\mathrm{b}}\end{array}$ & $\begin{array}{l}0.31 \mathrm{E}+13^{\mathrm{b}} \\
0.11 \mathrm{E}+13^{\mathrm{a}} \\
0.18 \mathrm{E}+13^{\mathrm{b}} \\
0.60 \mathrm{E}+13^{\mathrm{a}}\end{array}$ \\
\hline
\end{tabular}

\footnotetext{
$\overline{\mathrm{a}, \mathrm{b}}$ Values without a common superscript are significantly different (Tukey, $P<0.05$ ). Data comparisons were made between the 2 membranes. ${ }^{1}$ Based on triplicate experiments for the $0.1-\mu \mathrm{m}$ SW membrane and on duplicate experiments for the 0.1- $\mu \mathrm{m}$ GP membrane. Transmembrane pressure was $124.1 \mathrm{kPa}$ for the $\mathrm{SW}$ membrane and $151.7 \mathrm{kPa}$ for the GP membrane.

${ }^{2}$ Data on 0.1- $\mu \mathrm{m}$ GP membrane were taken from Tremblay-Marchand et al. (2016).

${ }^{3} \mathrm{SP}==$ serum proteins $(\mathrm{TP}-\mathrm{CN}) ; \mathrm{CN} \% \mathrm{TP}=$ caseins as percentage of true protein; $\mathrm{R}_{\mathrm{m}}=$ membrane resistance; $\mathrm{R}_{\mathrm{irr}}=$ irreversible resistance; $\mathrm{R}_{\text {rev }}=$ reversible resistance; $\mathrm{R}_{\text {tot }}=$ total resistance.
} 
Table 4. Comparative key performance characteristics and costs (Can $\$ / \mathrm{d})$ to process 1.5 million liters of milk per day $(20 \mathrm{~h}$ ) in the production of $\mathrm{CN}$ concentrates by microfiltration (MF)/diafiltration (DF) using a $0.1-\mu \mathrm{m}$ pore size spiral-wound (SW) and graded permeability (GP) membranes

\begin{tabular}{|c|c|c|}
\hline Item & $0.1-\mu \mathrm{m}$ SW & $0.1-\mu \mathrm{m}$ GP \\
\hline \multicolumn{3}{|l|}{ Raw material cost $(\mathrm{Can} \$ / \mathrm{d})$} \\
\hline Quantity of milk $\left(\times 10^{3} \mathrm{~kg}\right)$ & $1,519.5$ & $1,519.5$ \\
\hline Cost of milk ${ }^{1}$ & $1,215,600$ & $1,215,600$ \\
\hline \multicolumn{3}{|l|}{ Key performance characteristic } \\
\hline CN recovery (\% of initial) & 96.7 & 96.2 \\
\hline CN recovery $\left(\times 10^{3} \mathrm{~kg}\right)$ & 37.615 & 37.421 \\
\hline $\mathrm{CN}$ purity $($ ratio $\mathrm{CN} / \mathrm{TP} \times 100)$ & 89.22 & 91.57 \\
\hline CN flux $\left(\mathrm{kg} \cdot \mathrm{h}^{-1} \cdot \mathrm{m}^{-2}\right)$ & 0.363 & 1.38 \\
\hline Membrane area required $\left(\mathrm{m}^{2}\right)$ & $5,184.7$ & $1,353.6$ \\
\hline Energy requirement $\left(\mathrm{Wh} \cdot \mathrm{kg}^{-1} \mathrm{CN}\right)$ & 1,486 & 8,050 \\
\hline \multicolumn{3}{|l|}{ Membrane systems cost $(\mathrm{Can} \$ / \mathrm{d})$} \\
\hline Installation capital investment $^{2}$ & 228.63 & 944.43 \\
\hline Membrane depreciation $^{3}$ & 354.73 & 258.64 \\
\hline Energy $^{4}$ & $5,589.60$ & $30,161.40$ \\
\hline Cleaning $^{5}$ & $20,739.00$ & $5,414.40$ \\
\hline Maintenance $^{6}$ & 11.43 & 47.22 \\
\hline Membrane systems cost & $26,923.39$ & $36,826.08$ \\
\hline Total cost & $1,242,523.39$ & $1,252,426.08$ \\
\hline \multicolumn{3}{|c|}{${ }^{1}$ Cost of milk (based on milk payment to producers): $\$ 0.80 / \mathrm{kg}$ (Canadian $3 \mathrm{~b} .1$ class). } \\
\hline \multicolumn{3}{|c|}{$\begin{array}{l}{ }^{2} \text { Comparative capital investment costs (excluding membranes) of Can } \$ 321.02 / \mathrm{m}^{2} \text { for } \mathrm{SW} \text { membranes and } \\
\text { Can } \$ 5,079.37 / \mathrm{m}^{2} \text { for GP membranes. Depreciation of } 5 \% \text { per year applied. }\end{array}$} \\
\hline \multicolumn{3}{|c|}{$\begin{array}{l}{ }^{3} \mathrm{Purchase} \text { cost and lifetime of membranes are Can } \$ 300 \text { per module of } 6.69 \mathrm{~m}^{2} \text { for } 1.5 \mathrm{yr} \text { for SW; and Can } \$ 1,200 \\
\text { per module of } 0.72 \mathrm{~m}^{2} \text { for } 20 \mathrm{yr} \text { for GP. }\end{array}$} \\
\hline \multicolumn{3}{|c|}{${ }^{4}$ Energy costs established as per Hydro-Québec rate of Can $\$ 0.10 / \mathrm{kWh}$. } \\
\hline \multicolumn{3}{|c|}{${ }^{5}$ Cleaning costs estimates are Can $\$ 4 / \mathrm{m}^{2}$; data taken from Hu et al. (2015). } \\
\hline${ }^{6}$ Maintenance estimated at $5 \%$ of cap & ad Luque, 2010 & \\
\hline
\end{tabular}

The comparative economic analysis done by $\mathrm{Hu}$ et al. (2015) for membrane separation of CN and SP found that the capital investment for the GP membrane system was $27.0 \%$ higher than for the SW membrane system. In addition, both membrane replacement cost (35.0\% higher) and energy consumption were higher than for the SW membrane. However, the cost of cleaning the ceramic system was much lower due to the smaller membrane area. The irreversible resistances produced by fouling removed only by cleaning also resulted in lower cleaning costs for the GP membrane (Hu et al., 2015).

The comparative performance data reported in Table 3 can also be used to perform a techno-economic assessment of the SW and GP membranes. Table 4 presents a simulation based of comparative key performance characteristics and costs (Can $\$ / \mathrm{d})$ to process 1.5 million liters of milk per day $(20 \mathrm{~h})$ in the production of $\mathrm{CN}$ concentrates by MF/DF using a $0.1-\mu \mathrm{m}$ pore size SW and GP membranes. A CN flux $\left(\mathrm{kg} \cdot \mathrm{h}^{-1} \cdot \mathrm{m}^{-2}\right)$ was calculated from permeation flux and compositional values of the retentates. Casein flux values were, in turn, used to determine the membrane area $\left(\mathrm{m}^{2}\right)$ required for the process. According to the performance data, a SW system requires 3.8 -fold greater membrane area $(5,184$ vs. $1,353 \mathrm{~m}^{2}$ ) than the GP system; however, the GP system requires 5.4-fold more pumping energy than the SW system.

The economic evaluation of investment and operating costs of the 2 membrane systems reveals that, despite the distinctively higher purchase cost of GP membranes $\left(\$ 1,667 / \mathrm{m}^{2}\right.$ vs. $\left.\$ 45 / \mathrm{m}^{2}\right)$ and their higher energy requirements, the overall membrane systemrelated costs of the GP system is $37 \%$ higher than the SW system. The greater membrane area required for the SW systems translates into more important cleaning and replacement costs that offset the higher energy costs of the GP membrane. The longer lifetime of GP membranes (10 vs. 2.5 yr) also translates into lower yearly depreciation costs. Although these calculations are based on several assumptions that need more rigorous validation, they suggest that longer-term use of GP membranes may prove to be more efficient than SW membranes.

Another potentially interesting feature of the SW membrane is its high SP retention. When used to pre-concentrate cheese milk, this MF membrane could achieve high protein rejection while using less energy than the conventional $10 \mathrm{kDa}$ UF membrane normally used to prepare concentrates for cheesemaking. It will be important to compare the process efficiency of 0.1$\mu \mathrm{m}$ SW membranes with $10 \mathrm{kDa}$ UF membranes for 
the production of liquid pre-cheeses. Ultimately, the challenge will consist in be comparing the efficiency SP valorization in cheese in comparison to $\mathrm{SP}$ valorization as clean and functional ingredients (e.g., whey protein isolates) from MF permeate.

\section{CONCLUSIONS}

Our study indicates that the $0.1-\mu \mathrm{m}$ pore size diameter SW membrane is more suitable for $\mathrm{CN}$ rejection than the $0.2-\mu \mathrm{m}$ membrane. The relationship between the separation performance and the respective energy consumption of each membrane made it possible to calculate that the $0.1-\mu \mathrm{m}$ CGP membrane would be more efficient overall. However, the use of low-binding membrane polymers (e.g., polyethersulfone) and optimal feed spacer size and configuration are likely to improve SW membrane performance and modify the conclusions from the present techno-economic assessment. The combination of high permeate fluxes and high SP rejection of the $0.1-\mu \mathrm{m}$ SW membrane suggests that it may have some potential for use in the pre-concentration of milk in cheesemaking and could replace the use of UF to increase total proteins concentration for cheese milk.

\section{ACKNOWLEDGMENTS}

This research was funded by Natural Sciences and Engineering Research Council of Canada (Ottawa, $\mathrm{ON}$ ) and Novalait Inc. (Québec, QC, Canada). The authors thank R. J. Twiford from Tetra Pak Filtration Systems (Champlin, MN) for helpful discussions in the interpretation of our comparative techno-economic assessment of MF membranes. The authors also thank Diane Gagnon, Mélanie Martineau, Pascal Lavoie, and Léonie Régimbal from the Department of Food Science at Laval University for their technical assistance with experiments and analysis.

\section{REFERENCES}

AOAC International. 2000. Official Methods of Analysis. 17th ed. AOAC International, Gaithersburg, MD.

Bae, T. H., and T. M. Tak. 2005. Interpretation of fouling characteristics of ultrafiltration membranes during the filtration of membrane bioreactor mixed liquor. J. Membr. Sci. 264:151-160. https://doi .org/10.1016/j.memsci.2005.04.037.

Baruah, G. L., A. Nayak, and G. Belfort. 2006. Scale-up from laboratory microfiltration to a ceramic pilot plant: Design and performance. J. Membr. Sci. 274:56-63. https://doi.org/10.1016/j .memsci.2005.07.046.

Beckman, S. L., and D. M. Barbano. 2013. Effect of microfiltration concentration factor on serum protein removal from skim milk using spiral-wound polymeric membranes. J. Dairy Sci. 96:61996212. https://doi.org/10.3168/jds.2013-6655.

Beckman, S. L., J. Zulewska, M. Newbold, and D. M. Barbano. 2010. Production efficiency of micellar casein concentrate using polymer- ic spiral-wound microfiltration membranes. J. Dairy Sci. 93:45064517. https://doi.org/10.3168/jds.2010-3261.

Bowen, W. R., and Q. Gan. 1991. Properties of microfiltration membranes: Adsorption of bovine serum albumin at polyvinylidene fluoride membranes. J. Colloid Interface Sci. 144:254-262. https:// doi.org/10.1016/0021-9797(91)90256-8.

Britten, M., and Y. Pouliot. 1996. Characterization of whey protein isolate obtained from milk microfiltration permeate. Lait 76:255265. https://doi.org/10.1051/lait:1996321.

Cheryan, M. 1998. Ultrafiltration and Microfiltration Handbook. CRC Press, Lancaster, PA.

Fernández García, L., and A. R. Rodríguez. 2015. Microfiltration of milk with third generation ceramic membranes. Chem. Eng. Commun. 202:1455-1462. https://doi.org/10.1080/00986445.2014 .950731 .

Fox, P. F., and P. L. H. McSweeney. 2003. Advanced Dairy Chemistry. Dairy Chemistry and Biochemistry. 2nd rev. ed. Kluwer Academic/Plenum Publishers, New York, NY.

Garcera, D. and E. Toujas. 2002. Graded permeability macroporous support for crossflow filtration. Société des Céramiques Techniques, USPat. No. 6,375,014B1.

Garfin, D. E. 1990. One-dimensional gel electrophoresis. Pages 425441 in Guide to Protein Purification. Academic Press Inc., San Diego, CA.

Govindasamy-Lucey, S., J. J. Jaeggi, M. E. Johnson, T. Wang, and J. A. Lucey. 2007. Use of cold microfiltration retentates produced with polymeric membranes for standardization of milks for manufacture of pizza cheese. J. Dairy Sci. 90:4552-4568. https://doi .org/10.3168/jds.2007-0128.

Guerra, A., G. Jonsson, A. Rasmussen, E. Waagner Nielsen, and D. Edelsten. 1997. Low cross-flow velocity microfiltration of skim milk for removal of bacterial spores. Int. Dairy J. 7:849-861. https://doi .org/10.1016/S0958-6946(98)00009-0.

Hames, B. D. 1990. One-dimensional polyacrylamide gel electrophoresis. Pages 1-147 in Gel Electrophoresis of Proteins, A Practical Approach. B. D. Hames and D. Rickwood, ed. Oxford University Press, New York, NY.

Hassan, I. B., M. Ennouri, C. Lafforgue, P. Schmitz, and A. Ayadi. 2013. Experimental study of membrane fouling during crossflow microfiltration of yeast and bacteria suspensions: Towards an analysis at the microscopic level. Membranes 3:44-68. https://doi.org/ 10.3390/membranes3020044.

Hu, K., J. M. Dickson, and S. E. Kentish. 2015. Membrane Processing for Dairy Ingredient Separation. IFT Press. Wiley-Blackwell, Hoboken, NJ.

Hurt, E. E., M. C. Adams, and D. M. Barbano. 2015. Microfiltration of skim milk and modified skim milk using a $0.1-\mu \mathrm{m}$ ceramic uniform transmembrane pressure system at temperatures of 50,55 , 60, and $65^{\circ}$ C. J. Dairy Sci. 98:765-780. https://doi.org/10.3168/ jds.2014-8775.

Jimenez-Lopez, A. J. E., N. Leconte, O. Dehainault, C. Geneste, L. Fromont, and G. Gésan-Guiziou. 2008. Role of milk constituents on critical conditions and deposit structure in skimmilk microfiltration $(0.1 \mu \mathrm{m})$. Separ. Purif. Tech. 61:33-43. https://doi.org/10 .1016/j.seppur.2007.09.023.

Jirjis, B. F., and S. Luque. 2010. Practical aspects of membrane system design in food and bioprocessing applications. Pages 179-212 in Membrane Technology. Elsevier. https://doi.org/10.1016/B978 -1-85617-632-3.00009-4.

Johnson, J. E. 2013. Design and construction of commercial spiral wound modules. Pages 1-21 in Encyclopedia of Membrane Science and Technology. E. M. V. Hoek and V. V. Tarabara, ed. John Wiley and Sons, Inc.

Karasu, K., N. Glennon, N. D. Lawrence, G. W. Stevens, A. J. O'Connor, A. R. Barber, S. Yoshikawa, and S. E. Kentish. 2010. A comparison between ceramic and polymeric membrane systems for casein concentrate manufacture. Int. J. Dairy Technol. 63:284-289. https://doi.org/10.1111/j.1471-0307.2010.00582.x.

Lawrence, N. D., S. E. Kentish, A. J. O'Connor, A. R. Barber, and G. W. Stevens. 2008. Microfiltration of skim milk using polymer- 
ic membranes for casein concentrate manufacture. Separ. Purif. Tech. 60:237-244. https://doi.org/10.1016/j.seppur.2007.08.016.

Nelson, B. K., and D. M. Barbano. 2005. A microfiltration process to maximize removal of serum proteins from skim milk before cheese making. J. Dairy Sci. 88:1891-1900. https://doi.org/10.3168/jds .S0022-0302(05)72865-4.

Papadatos, A., M. Neocleous, A. M. Berger, and D. M. Barbano. 2003. Economic feasibility evaluation of microfiltration of milk prior to cheesemaking. J. Dairy Sci. 86:1564-1577. https://doi.org/10 .3168/jds.S0022-0302(03)73742-4.

Pouliot, Y. 2008. Membrane processes in dairy technology-From a simple idea to worldwide panacea. Int. Dairy J. 18:735-740. https://doi.org/10.1016/j.idairyj.2008.03.005.

Saboya, L. V., and J.-L. Maubois. 2000. Current developments of microfiltration technology in the dairy industry. Lait 80:541-553. https://doi.org/10.1051/lait:2000144.

Steinhauer, T., M. Marx, K. Bogendörfer, and U. Kulozik. 2015. Membrane fouling during ultra- and microfiltration of whey and whey proteins at different environmental conditions: The role of aggregated whey proteins as fouling initiators. J. Membr. Sci. 489:2027. https://doi.org/10.1016/j.memsci.2015.04.002.
Tong, P. S., D. M. Barbano, and M. A. Rudan. 1988. Characterization of proteinaceous membrane foulants and flux decline during the early stages of whole milk ultrafiltration. J. Dairy Sci. 71:604-612. https://doi.org/10.3168/jds.S0022-0302(88)79597-1.

Tremblay-Marchand, D., A. Doyen, M. Britten, and Y. Pouliot. 2016. A process efficiency assessment of serum protein removal from milk using ceramic graded permeability microfiltration membrane. J. Dairy Sci. https://doi.org/10.3168/jds.2016-10914.

Zulewska, J., and D. M. Barbano. 2013. Influence of casein on flux and passage of serum proteins during microfiltration using polymeric spiral-wound membranes at $50^{\circ} \mathrm{C}$. J. Dairy Sci. 96:2048-2060. https://doi.org/10.3168/jds.2012-6032.

Zulewska, J., and D. M. Barbano. 2014. The effect of linear velocity and flux on performance of ceramic graded permeability membranes when processing skim milk at $50^{\circ} \mathrm{C}$. J. Dairy Sci. 97:26192632. https://doi.org/10.3168/jds.2013-7635.

Zulewska, J., M. Newbold, and D. M. Barbano. 2009. Efficiency of serum protein removal from skim milk with ceramic and polymeric membranes at 50 degrees C. J. Dairy Sci. 92:1361-1377. https:// doi.org/10.3168/jds.2008-1757. 